\title{
Attracting East Asian Students to Canadian Graduate Schools
}

\author{
Liang-Hsuan Chen \\ University of Toronto at Scarborough
}

\begin{abstract}
This study seeks to identify factors influencing East Asian international students' choices of Canadian graduate schools, to assess the strengths and dynamics of the factors influencing enrolment decisions, and to describe possible implications both for the Canadian government and for Canadian universities offering graduate education. The research sample comprised 140 students from China, Hong Kong, Japan, Korea, and Taiwan who enrolled in graduate programs at two large Ontario universities. The research findings reveal the significant influence of academic, economic, environmental, and visa/immigration pulling factors as well as a set of negative pushing factors from third countries such as the United States. Activities related to internationalization of graduate education play a critical role in influencing the choice of a Canadian graduate school. The findings suggest that to attract the "best and brightest" international graduate students, policy makers and institutional administrators should focus on investing in research and ensuring the quality of graduate education while devoting efforts and resources to the internationalization of Canadian graduate education.
\end{abstract}

\section{RÉSUMÉ}

Cet article porte sur la décision, par les étudiants internationaux de l'Asie orientale, d'étudier aux cycles supérieurs dans une université canadienne. L'étude cherche à identifier les facteurs influençant ce choix, à évaluer les forces et la dynamique des facteurs influençant la décision d'inscription, et à décrire des implications possibles pour le gouvernement canadien et pour les universités canadiennes. 
L'échantillon est composé de 140 étudiants originaires de Chine, de Hong Kong, du Japon, de Corée et de Taiwan qui s'étaient inscrits dans des programmes de cycle supérieur à deux grandes universités ontariennes. Les résultats de la recherche révèlent l'influence significative des facteurs académiques, économiques, environnementaux, et associés aux règles de l'immigration, ainsi qu'un ensemble de facteurs négatifs associés à des pays tiers tels que les États-Unis. Les activités faisant la promotion de l'internationalisation des cycles supérieurs jouent un rôle critique et influencent le choix d'une université canadienne à cet ordre d'enseignement. Les résultats suggèrent que, pour attirer les meilleurs étudiants internationaux aux cycles supérieurs, les décideurs gouvernementaux et les administrateurs institutionnels devraient investir dans la recherche et assurer la qualité de la formation aux cycles supérieurs, tout en consacrant efforts et ressources à l'internationalisation des programmes de cycles supérieurs au Canada.

International graduate students, belonging to the so-called "creative class" (Florida, 2002), are a very special group of people who travel from afar to pursue advanced education both for the love of knowledge and for personal and professional advancement. They play an important role in Canadian graduate education by bringing academic, cultural, and economic benefits to the learning environment and society; subsequently, they are ambassadors of Canadian education to the world. Despite their importance, existing research on international graduate students, especially in the Canadian context, is minimal. This is the first research focusing on this group of international students and their choices of Canadian graduate schools.

Canada's future sustainability and growth will depend on new immigrants who are educated skilled workers. The international student population has been viewed by many as a pool of preferred potential immigrants. The 2002 Speech from the Throne, The Canada We Want, outlined the need for Canada to be a magnet for talent and investment. In particular, the government vowed to "position Canada as a destination of choice for talented foreign students and skilled workers by more aggressively selecting and recruiting through universities and in key embassies abroad" (Government of Canada, 2002, p. 9). It is clear that all levels of government in Canada and most institutions have a great interest in international students. The challenge that Canada faces is that we know very little about international students' choices, in particular, at the level of graduate students. What do we know about international graduate students? Who are they? What motivates them to pursue international study? What factors determine their final decision of a host country and a host institution? As a country providing international education, we know very little about the answers to these questions. In addition, we do not know whether Canada's policies or strategies have made a significant impact in advancing Canada's agenda. 
This challenge can only be addressed by gaining insights into the major factors influencing the choice of Canada by international students as a destination for higher learning. Understanding these factors will advance Canada's agenda of attracting the best and brightest international students to Canada.

\section{THEORETICAL FRAMEWORK}

The existing "college choice" literature gives little consideration to the unique characteristics of international graduate students. Typically, the literature groups them with other graduate students or with undergraduate international students. For the purpose of this study, a push-pull model was used to understand the strengths of and relationships among various factors that influence the choice of a country, institution, program, and city. In addition, literature on internationalization of higher education was examined for insights on how it impacted the international graduate students' decision-making processes and choices of particular institutions and programs.

A push-pull model was originally used in the theory of migration (E. S. Lee, 1966) to explain the factors influencing the movement of people. The model has been used to understand international student flows (Agarwal \& Winkler, 1985; Cummings, 1984; Cummings \& So, 1985; K.H. Lee \& Tan, 1984; Neice \& Braun, 1977; Sirowy \& Inkeles, 1984), the decision or motivation to study abroad (Altbach \& Lulat, 1985; Glaser \& Habers, 1978; Rao, 1979), and choice of country by international students (Mazzarol \& Soutar, 2002). Push factors are factors associated with the home country. Some push factors are positive and some are negative in nature. Pull factors are generally positive factors that attract international students to the destination. In essence, the decision, motivations and flow of international students are "a function of the combined 'pull' factors and 'push' factors as influenced by intervening obstacles" (Sirowy \& Inkeles, 1984, p.65). Neice and Braun (1977) explain that the push factors have strength in the initial reasons for studying abroad while the pull factors dominate the choices, especially the appeal of program availability.

From a macro perspective, many studies have taken economic and political approaches to examining international student flows. McMahon (1992) argues that the flow of knowledge resources among nations is interconnected with global political, economic, and cultural relationships. Important push factors for international student flows include excess demand (especially in the science fields) relative to the availability of educational opportunities in the home country and financial capability, wealth, and GNP growth. Important pull factors include the home country's economic development and involvement in the world because international student flows are related to the level of economic development in a country (Agarwal \& Winkler, 1985; Chen \& Barnett, 2000; Cummings \& So, 1985; K. H. Lee \& Tan, 1984; McMahon, 1992).

The push-pull model has been primarily used to explain international students' decision-making process in the first two stages: (1) the "predisposition" 
(Hossler \& Gallagher, 1987) or motivation stage - the decision to study abroad, and (2) the "search" or information gathering stage - the choice of a country. This study takes this model one step further, to the last stage of the decision-making process described by Hossler and Gallagher - (3) the "choice" of an institution because this model touches on the academic, economic, environmental and informational factors closely tied to other college choice models.

Internationalization of higher education has become an integral part of higher education and will continue to be "a major theme for the next decade" (Davies, 1997, p. 83). Most of the literature on internationalization is written from the perspective of a nation or an institution, and very little examines internationalization from international students' perspectives, especially in relation to its impact on their choices of institutions and/or programs. An activity approach is "most widely used in the description of internationalization, and terms related to this approach are frequently used as being equivalent to the internationalization of higher education" (de Wit, 2002, p. 116). Knight took a process approach and defined internationalization as "integrating an international/intercultural perspective into the teaching/learning, research and service functions of a higher education institution" (2000, p. 16). Fortin (2001) notes that most Canadian universities take a process approach to internationalization. The internationalization of higher education, regardless of the approaches an institution takes, acts in concert with push-pull factors influencing international graduate students' choice of a Canadian graduate school.

\section{METHODOLOGY}

This study used a combination of quantitative and qualitative research methods. Quantitative data collected from mailed survey questionnaires were used to identify the factors and to measure their significance in influencing or determining the choice of overseas graduate schools. Qualitative data from inperson interviews were used to gain insights into how international graduate students decide to pursue international studies and select a country, institution, program and location. Triangulation was used in this research to determine the consistency of data collected from both methods, and the research findings were compared to the findings from the literature review.

The survey items were developed based on a review of previous questionnaires (Austin, 1988; Gagnon \& Cocolas, 1988; Neice \& Braun, 1977; Olson, 1992; Poock \& Love, 2001; Webb, 1993; Zikopoulos \& Barber, 1986), and these items were grouped into three domains of factors - Student Characteristics, Significant Others, and External Push-Pull factors. The structure of the survey questionnaire followed the flow of the study-abroad decision - choice of country, choice of institution/program, and future plans.

The research participants included international graduate students from China, Hong Kong, Japan, Korea, and Taiwan who were enrolled in two large universities in the city of Toronto - the University of Toronto and York 
University - in the academic year of 2003-04. These East Asian jurisdictions were chosen because of their importance as a source of graduate students across North America. International students from these jurisdictions represented almost one-fifth of the graduate level international enrolment in Canada for the three academic years 1997-2000 (Bartlett \& Kane, 2002), and international graduate students from these jurisdictions represented $41 \%$ of total international graduate student enrolment in the United States (Davis, 2000). Prior to 1994, Hong Kong and Japan were leading countries sending students to Canada, representing almost 30\% and 18\% respectively of total international students in Canada. However, after 1994, Korea and China became the leading countries sending students to Canada. In 2001, international students from Hong Kong, Japan, Korea and China represented 5\%, 8\%, 15\% and 15\% respectively of total international students in Canada (Citizenship and Immigration Canada, 2003). Although Hong Kong is now part of China, its history of being part of the Commonwealth had a significant impact on the pattern of sending students to Canada compared with the Chinese experience, and so the data on these subsamples were collected and analyzed separately.

The University of Toronto and York University were chosen because they have the largest and eighth largest graduate enrolments in Canada, respectively. In 2001, the University of Toronto had a total graduate student enrolment of 10,665, of whom 2,605 were international; while York University, with a strong focus on social science graduate programs, had a total graduate enrolment of 4,260, of whom 975 were international (Canadian Association for Graduate Studies, 2004). The city of Toronto was chosen mainly to explore the causal relationship between the location and enrolment decision: among the 43 North American metropolitan regions with populations over one million, the city of Toronto has been ranked number one in diversity (the "Mosaic Index") and number four in creativity (the "Bohemian Index") (Gertler, Florida, Gates, \& Vinodrai, 2002).

Survey questionnaires were mailed to a total population of 480 students, of which approximately 30 were returned as undeliverable. Besides the country of origin, there was no additional information available on the population regarding gender, age, level of study, and the field of study. One hundred and forty surveys $(31 \%)$ were returned. The recruitment of the interview participants was via selfselection. The interview participants were asked in the questionnaire whether they would be interested in participating in an in-depth interview. Thirtyfour students provided their contact information to participate in the in-depth interview and twenty-three of those who volunteered actually participated. For purposes of descriptive comparison, six independent variables were selected and compared: (1) university enrolled, (2) level of study, (3) field of study, (4) gender, (5) country of origin, and (6) attitude/preference (i.e., whether Canada was the country of first choice). For the qualitative research portion of the study, the in-depth interview was semi-structured. The interview format consisted of small group discussions, individual interviews, and one on-line interview. 
The respondents mirrored the total population in terms of country of origin (refer to Table 1). Half of the respondents were enrolled at the doctoral level, and the balance of the respondents were enrolled at the Master's level. Thirtytwo percent of the respondents were between 21 and 25 years of age, 47\% were between 26 and 30, and 21\% were over 30 years of age. Twenty-two percent of the respondents were enrolled in arts and humanities, 27\% in business, 7\% in education, 34\% in engineering and science, $2 \%$ in law, and 6\% in medical and health. The composition and background of the interviewees is shown in Table 2.

Table 1.

Total population vs. survey respondents

\begin{tabular}{lcrcr}
\hline Country & Total Population & $\%$ & $\begin{array}{c}\text { Survey } \\
\text { Respondents }\end{array}$ & $\%$ \\
\hline China & 323 & 67 & 89 & 64 \\
Hong Kong & 20 & 4 & 6 & 4 \\
Japan & 62 & 13 & 24 & 17 \\
Korea & 54 & 11 & 10 & 7 \\
Taiwan & 20 & 4 & 11 & 8 \\
Total & 479 & 100 & 140 & 100 \\
\hline
\end{tabular}

Table 2.

The composition and background of the interviewees

\begin{tabular}{lccccccrr}
\hline Country & \multicolumn{2}{c}{ Gender } & \multicolumn{2}{c}{ University } & \multicolumn{2}{c}{ Level of Study } & Total & $\%$ \\
\cline { 1 - 7 } China & Male & Female & UT & York & Doctoral & Master & & \\
\cline { 2 - 7 } Hong Kong & 7 & 2 & 6 & 3 & 5 & 4 & 9 & 39 \\
Japan & 1 & 1 & 1 & 1 & 1 & 1 & 2 & 9 \\
Korea & 2 & 6 & 5 & 1 & 4 & 2 & 6 & 26 \\
Taiwan & 3 & 1 & 1 & 3 & 1 & 3 & 4 & 17 \\
$\quad$ Total & 13 & 10 & 14 & 9 & 13 & 10 & 23 & 100 \\
\hline
\end{tabular}




\section{RESULTS}

\section{Applications Pattern and Preference/Attitude}

Seventy-one respondents (51\%) reported that Canada was their first choice, while 67 respondents (49\%) reported that Canada was not their first choice. The vast majority (92\%) of the respondents reported that their program of study was their first choice, and 81\% of the respondents reported that their university was their first choice in Canada. Two-thirds of those who reported that their university was not their first choice identified American universities as their first choice.

Significant differences were observed in the responses based on respondents' country of origin and between males and females. Among the five groups, the majority of Japanese, Hong Kong, and Korean students reported that Canada was their first choice country, while half of the Taiwanese students reported that Canada was their first choice country. More than half (63\%) of the Chinese students reported that Canada was not their first choice country. More female than male students preferred Canada as their first choice country.

Almost all (65 respondents or 98\%) of those respondents reporting that Canada was not their first choice of country identified the United States as their first choice of country. Although 71 respondents reported that Canada was their first choice country, $89(64 \%)$ respondents had applied to universities outside Canada. The United States was the country most respondents (70) identified as the country to which they applied. It is evident that outside of Canada, the United States was the preferred country for graduate studies for this sample.

\section{Factors Influencing Study Abroad}

The decision to undertake overseas graduate study is influenced by three domains of factors - Student Characteristics, Significant Others, and External Push-Pull Factors. Among these factors, Student Characteristics showed the strongest influence, followed by positive Push Factors from Home Country, Pull Factors from Canada, and finally Significant Others. In reviewing pushpull factors related to the respondents' home countries and Canada, it is worth noting that positive push factors exerted more influence than negative push factors in making the decision to study abroad. In aggregate, one of the least important factors related to the study abroad decision was the influence from significant others. "Family (children)/spouse" was identified by some married students as a factor influencing the study abroad decision, suggesting a possible intention to immigrate.

There is a significant difference by country of origin in the perceived benefits of studying abroad (refer to Table 3). Studying abroad was viewed positively in China, Korea and Taiwan, but it was perceived negatively in Japan. In fact, many Japanese students mentioned that overseas graduate study was not considered a favourable undertaking. These students tended to rank 
Table 3.

Summary of Reasons Influencing Study Abroad Decision by Country of Origin

\begin{tabular}{|c|c|c|c|c|c|}
\hline & China & $\mathrm{HK}$ & Japan & Korea & Taiwan \\
\hline & M & M & M & M & M \\
\hline I want an advanced degree for personal satisfaction & 4.27 & 3.83 & 4.13 & 4.10 & 4.18 \\
\hline Foreign language skills are desirable & 4.18 & 3.83 & 3.75 & 4.40 & 4.64 \\
\hline $\begin{array}{l}\text { Foreign advanced degrees improve job prospects/the } \\
\text { chance of receiving a good salary and promotions }\end{array}$ & 4.09 & 3.83 & 3.13 & 3.90 & 4.36 \\
\hline My profession requires an advanced degree & 4.08 & 4.40 & 3.52 & 3.56 & 4.45 \\
\hline The opportunity to experience a Western culture & 4.07 & 3.50 & 3.04 & 3.90 & 4.45 \\
\hline $\begin{array}{l}\text { The work experience abroad is valued by my home } \\
\text { country }\end{array}$ & 4.04 & 3.83 & 2.77 & 4.20 & 4.27 \\
\hline I value an advanced degree from a Western country & 4.01 & 3.83 & 2.86 & 3.60 & 3.73 \\
\hline $\begin{array}{l}\text { The foreign degrees are prestigious or valued by my } \\
\text { home country }\end{array}$ & 3.95 & 3.33 & 2.86 & 3.90 & 4.18 \\
\hline $\begin{array}{l}\text { Prospects of better employment and higher salary } \\
\text { after study abroad }\end{array}$ & 3.88 & 3.67 & 3.14 & 3.70 & 4.45 \\
\hline $\begin{array}{l}\text { International education is valued by my home } \\
\text { country }\end{array}$ & 3.88 & 3.67 & 2.87 & 3.90 & 4.09 \\
\hline Family/Spouse & 3.50 & 4.40 & 3.89 & 3.10 & 3.73 \\
\hline Other Students/Friends & 3.04 & 3.50 & 3.48 & 3.11 & 3.44 \\
\hline Home country lacks research facilities & 2.86 & 3.60 & 2.85 & 2.70 & 2.40 \\
\hline Professors & 2.70 & 4.40 & 4.18 & 2.40 & 3.57 \\
\hline Desired education not available & 2.68 & 2.75 & 3.75 & 3.13 & 2.89 \\
\hline Alumni & 2.37 & 3.00 & 2.31 & 2.78 & 1.75 \\
\hline Limited career prospects at home & 2.29 & 3.20 & 2.62 & 2.70 & 2.78 \\
\hline Uncertain political situation & 1.85 & 2.33 & 1.13 & 1.33 & 1.89 \\
\hline Relatives in the host country & 1.85 & 3.75 & 2.54 & 2.25 & 2.14 \\
\hline The opportunity to gain freedom from family & 1.72 & 2.20 & 2.20 & 2.22 & 2.60 \\
\hline Sponsor & 1.67 & 3.00 & 2.55 & 1.50 & 2.00 \\
\hline Financial support from home government or agency & 1.56 & 4.40 & 3.00 & 2.00 & 2.14 \\
\hline Employers & 1.46 & 3.50 & 1.55 & 2.29 & 3.43 \\
\hline
\end{tabular}

Results based on a Likert scale of $1-5$, where $1=$ unimportant and $5=$ very important. 
low in importance the value or the economic benefits of foreign education in their society and identified a "reverse push" factor from their country because Japanese society puts less importance on foreign graduate education. Many said a foreign education could actually have a negative effect on their future career if they returned to Japan. As one student put it,

for Japanese students to study abroad is not a good idea, if you want to go back to Japan... One thing you are older than the rest of Japanese who have same degree. Other thing is they look at you like you are from outside. They don't want to take you and they don't want to give you a job. You are from outside, you have different way of doing things. Employers would prefer Japanese Ph.D. to foreign Ph.D., and masters as well. If you want to get a job in Japan, it is better for a student to study master program in Japan. Also, the connection is very important, such as network of people is very important to get a job. If you are abroad, it is very hard to have the network in Japanese society. If I did my graduate work in Japan, I would have contact with lots of Japanese professors. I can do more networking there, so I will have higher opportunity. It is not that Japanese education is better than the western education; it is that the culture of the work place is important. If I graduate from Canada and go back to Japan I may be able to write publications in English much faster than they can, and they may be older than me. They feel this is an annoyance, it is just like you just came in, you can do something academically faster.

\section{Factors Influencing Choice of Canada}

The choice of Canada was mostly influenced by the Pull Factors from Canada, followed by the Push Factors Related to Home Country, then the Significant Others factors. Among the four sub-sets of Pull Factors from Canada, factors related to Canadian Environment exerted the most influence in pulling international students to Canada, followed by Economic/Costs and Visa/Immigration factors.

Most international students in the research sample had a favourable impression of the Canadian environment. On one hand, those who said that Canada was their first-choice country typically reported that they came to Canada because of the positive Canadian environment - safe, diverse and multicultural (refer to Table 4). This indicates that their personal preferences were aligned with the unique features and social philosophy that Canada has to offer. On the other hand, those students who reported that Canada was not their first-choice country chose to come to Canada for utilitarian reasons, such as ease of visa/immigration, financial aid, and proximity to the U.S.

As seen in Table 5, the factors influencing the choice of Canada varied significantly among these five groups of students. 
Table 4

Reasons for Choosing Canada, by whether Canada was first-choice country

Canada was Canada was NOT my $1^{\text {st }}$ Choice my $1^{\text {st }}$ Choice

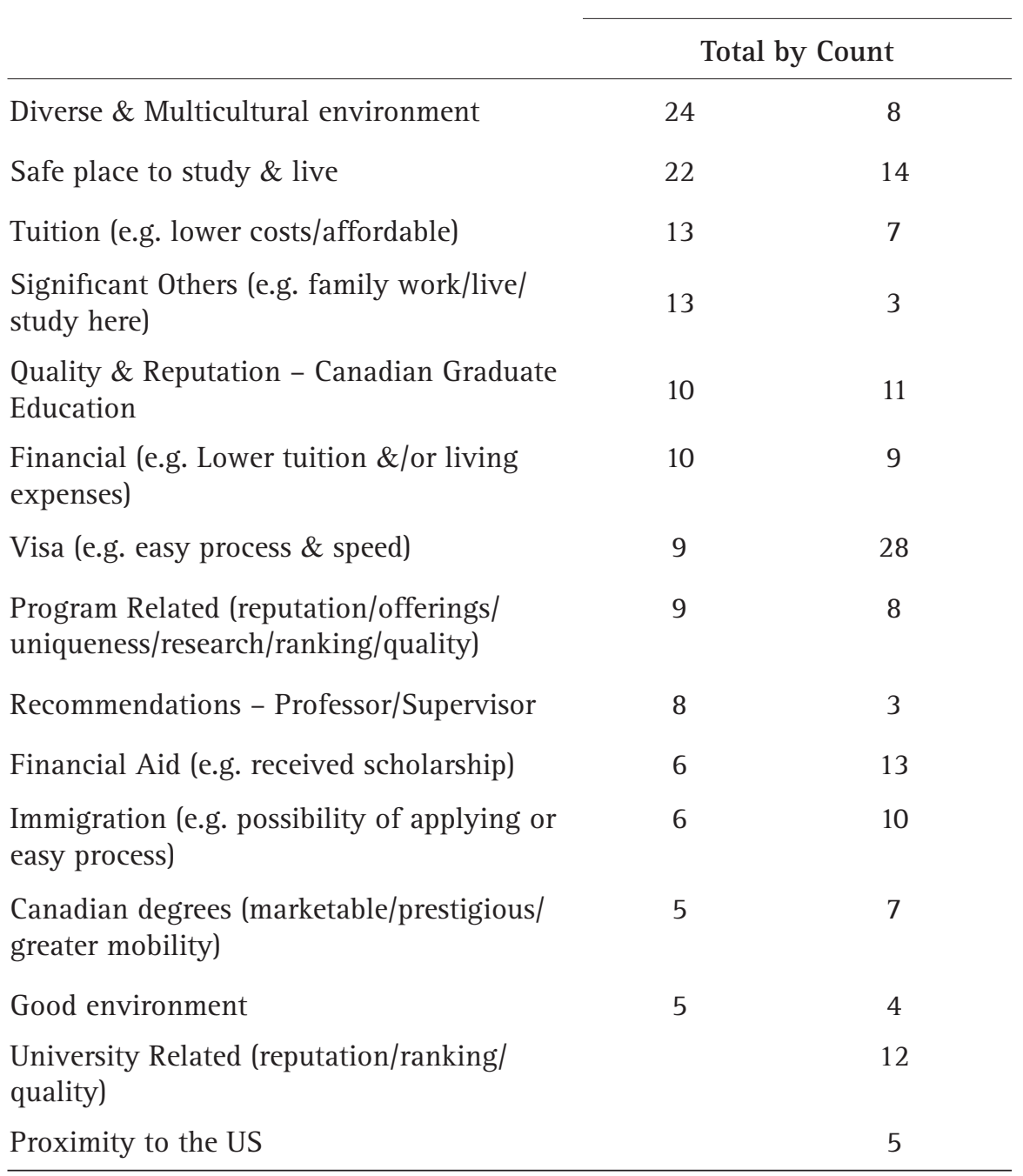


Table 5.

Reasons for Choosing Canada, by Country of Origin

\begin{tabular}{|c|c|c|c|c|c|}
\hline & China & HK & Japan & Korea & Taiwan \\
\hline & \multicolumn{5}{|c|}{ Total by Count } \\
\hline Visa (e.g. easy process \& speed) & 35 & & & & 1 \\
\hline Safe place to study \& live & 18 & & 9 & 5 & 4 \\
\hline Diverse \& Multicultural environment & 18 & & 9 & 1 & 4 \\
\hline $\begin{array}{l}\text { Quality \& Reputation - Canadian } \\
\text { Graduate Education }\end{array}$ & 18 & & & & 2 \\
\hline $\begin{array}{l}\text { Financial Aid (e.g. received } \\
\text { scholarship) }\end{array}$ & 15 & & 3 & & 1 \\
\hline $\begin{array}{l}\text { University Related (reputation/ranking/ } \\
\text { quality) }\end{array}$ & 14 & & & 1 & \\
\hline $\begin{array}{l}\text { Immigration (e.g. possibility of } \\
\text { applying or easy process) }\end{array}$ & 11 & & & 3 & 2 \\
\hline $\begin{array}{l}\text { Canadian Degrees (marketable/ } \\
\text { prestigious/greater mobility) }\end{array}$ & 11 & 1 & & & \\
\hline Tuition (e.g. lower costs/affordable) & 8 & & 4 & 2 & 5 \\
\hline $\begin{array}{l}\text { Significant Others (e.g. family work/ } \\
\text { live/study here) }\end{array}$ & 7 & 3 & 3 & 2 & 2 \\
\hline $\begin{array}{l}\text { Program Related (reputation/offerings/ } \\
\text { uniqueness/research/ranking/quality) }\end{array}$ & 6 & 1 & 6 & 2 & 2 \\
\hline $\begin{array}{l}\text { Financial (e.g. Lower tuition \&/or } \\
\text { living expenses) }\end{array}$ & 6 & 1 & & 4 & 5 \\
\hline Proximity to the US & 6 & & & 1 & \\
\hline $\begin{array}{l}\text { Recommendations - Professor/ } \\
\text { Supervisor }\end{array}$ & 5 & 1 & 4 & 1 & \\
\hline Good Environment & 5 & & & & \\
\hline $\begin{array}{l}\text { Quality of life, health, professional } \\
\text { working environment }\end{array}$ & 5 & & & 2 & 1 \\
\hline Professor Related (research/reputation) & & & 4 & & \\
\hline
\end{tabular}


To add to Neice and Braun's (1977) four main groups of reasons for choosing Canada - associates' experiences, cultural context, educational system, and financial considerations - the research findings show that in the post-September 11 era, visa and immigration considerations are of great importance in choosing Canada for particular groups of students. Many Chinese students would have preferred the United States as a destination; however, they were unable to obtain U.S. student visas, and as a consequence, they accepted Canada as their second choice for the ease and speed of the Canadian visa process. None of the other four groups of international students mentioned the issue of difficulty in obtaining U.S. student visas.

For many self-funded masters students, the cost of graduate education and living expenses were a concern. They were looking for a high-perceived quality of education at competitive costs. Regarding information factors, students reported that it was much harder to obtain information on studying in Canada than for other countries; therefore, the information factors and marketing of Canadian education did not play an important role in influencing their choice of Canada.

Push Factors from Home Country did not exert a strong influence on international students' choice of Canada. International students reported that the economic and political ties between Canada and the home country were considered to be of very low importance in influencing their choice of Canada. More than half of the research sample reported that they did not have family/ associate ties in Canada, so the influence from Significant Others on their choice of Canada was either not applicable or very minimal. Only students from Hong Kong reported the family/associate tie to Canada to be more important in choosing Canada. This may be the result of the long history of Hong Kong students pursuing post-secondary education in Canada when Hong Kong was part of the Commonwealth.

\section{Factors Influencing Choice of an Institution}

The key factors influencing the choice of an institution are Academic Pulling Factors and Administrative Pulling Factors. The Academic Pulling Factors were ranked with very high importance, and in general, university reputation/ quality/ranking was ranked with a higher importance than program reputation/ quality/ranking. Following these pulling forces were the Administrative Pulling Factors, such as availability of financial aid and cost issues, and the interaction with faculty and staff.

In essence, these are core factors that pervade the entire study abroad process and that exert an important pulling effect in drawing international graduate students to Canada and to Canadian graduate schools. In addition, the research findings show that engineering and business students were familiar with the school and program ranking information, and they relied heavily on the ranking information to make selection, application, and choice decisions. Students from China, Hong Kong, and Taiwan rated the importance of the 
university and program ranking higher than students from Japan and Korea. The findings showed that the ranking information was important not so much for reducing risks, but more for economic and return on investment purposes. In other words, these students perceived that a graduate degree from a top-ranked engineering or business school/program would improve their future career and job prospects. The other important factor related to Academic Pulling Factors was the quality/reputation of faculty and their research focus. Some international students reported in the interviews that they came to Canada solely because they wanted to study under their professor/supervisor, and they were interested in specific research topics of their professors. Table 6 and Table 7 show the important factors ranked by level of study and by university enrolled.

Administrative Pulling Factors were ranked with relatively high importance, and the two most significant factors were "uniqueness of program and course offering" and "positive interaction with faculty and staff." Although these factors were important in pulling international students to a Canadian graduate school, they were still secondary to the Academic Pulling Factors.

Location factors played an important role throughout the decision-making process as to search/select/application process, and again at the choice stage

Table 6.

Reasons for Choosing an Institution, by Level of Study

\begin{tabular}{lcc}
\hline & Doctoral & Master's \\
\cline { 2 - 3 } & \multicolumn{2}{c}{ Total by Count } \\
\hline Financial Aid (e.g. received scholarship) & 32 & 20 \\
University - Reputation & 28 & 23 \\
Faculty (e.g. Reputation \& Quality) & 22 & 8 \\
Program - Reputation & 17 & 20 \\
Program - Ranking & 10 & 16 \\
University - Ranking & 9 & 15 \\
Program Related (e.g. uniqueness/course offering/ & 8 & 16 \\
requirements) & & 8 \\
Program - Quality & 8 & 19 \\
Location of university & 7 & 6 \\
Recommendations - Professor/Supervisor & 7 & 5 \\
Positive Interaction with faculty/staff & 6 & \\
Research Project \& Topic Area & 4 & 6 \\
University - Quality & 3 & \\
Previously studied at the same university & 3 & \\
Career enhancement (degree from this university) & 3 & \\
Tuition (e.g. lower costs/affordable) & & \\
\hline
\end{tabular}


Table 7.

Reasons for Choosing an Institution, by University Enrolled

\begin{tabular}{lcc}
\hline & U of T & York \\
\cline { 2 - 3 } & \multicolumn{2}{c}{ Total by Count } \\
\hline University - Reputation & 45 & 6 \\
Financial Aid (e.g. received scholarship) & 35 & 17 \\
Program - Reputation & 25 & 12 \\
University - Ranking & 19 & 5 \\
Faculty (e.g. Reputation \& Quality) & 17 & 13 \\
Program Related (e.g. uniqueness/course offering/requirements) & 16 & 8 \\
Location of university & 15 & 11 \\
Program - Quality & 13 & \\
Program - Ranking & 11 & 13 \\
University - Quality & 9 & \\
Recommendations - Professor/Supervisor & 9 & \\
Tuition (e.g. lower costs/affordable) & 5 & 7 \\
\hline
\end{tabular}

process. Many international students expressed a preference for attending a graduate school located in a metropolitan city, since they were used to living in a similar environment in their own country. International students were concerned about issues such as safety, discrimination and tolerance (being accepted), diversity, and multiculturalism within a city and within an institution. They considered the reasons "the city where my university is located is safe," "there is no discrimination against me at this university," "the location of the university," and "the diversity of the city where my university is located" to be important in choosing a graduate school. The findings are consistent with Florida's (2002) theory that knowledge workers are attracted to cities with tolerant environments and diverse populations.

\section{Key Findings from the In-depth Interviews}

Based on the survey questionnaire results and supported by the interviews, the majority of international students considered the program characteristics first because the program specialization or uniqueness determined which countries and institutions to pursue for further information and to make an application. This may have been due to the fact that the students in question were graduate students and the area of study was therefore of great importance. Once they determined the program of study, they then tended to consider multiple institutions in various countries and cities. One student explained, 
the main reason for me study in Canada is that I am interested in Canada, as a country consisting of so many immigrants. I could have studied about Canada in Japan, in the United States, or in Canada. So, basically, I had three choices. . . I started to think that I couldn't study fully about Canada if I stayed in Tokyo, or in Japan. So, I decided to study abroad in North America. I did some web research in sociology programs in the states and in Canada. . . All of the universities have better points and bad points, but on the whole, for me, $\mathrm{U}$ of $\mathrm{T}$ would be the best place for me to study immigrant community in Canada because $U$ of $T$ sociology department has good professors, a number of professors for specializing immigration, as well as quantitative study in immigration, like demography, demographic aspects of immigration. Or some professors use census data or that kind of quantitative data to analyze immigrant society. Actually, I was more interested in quantitative study than qualitative study. . . For me, the content of the program is quite a strong factor that made me decide.

Internationalization activities, such as faculty exchange, collaborations, and attending international conferences and publishing research papers, played a crucial role in guiding these international graduate students' searches, application and choice processes. The following comments illustrate how the internationalization activities guided these international graduate students' decision-making process of a Canadian graduate school.

I talked with my supervisors about which schools should be good for my Ph.D. My supervisor was a visiting scholar at OISE, and she told me that this institution is very good for my future study. . . I didn't want to go to the U.S. because I study second language education, and the policy in the States is not good. I prefer language courses in Canada. I heard there is some discrimination towards people who can't speak English well in the United States. That kind of discrimination is small in Canada. I talked with some people in Canada before I came here about the language situation here. One person told me that she had never felt any discrimination about language here. Plus, Canada has bilingual policy and it is famous for bilingual education, so I wanted to come to Canada... I also included universities in England, but I applied to $\mathrm{U}$ of $\mathrm{T}$ first.

For the political science program in Canada, I worked with one professor in the Department of Economics at Seoul National University. He presented his article in the Department of Political Science at York University in 1998. I worked with that professor around that time, so I knew the political science program at York through this professor, and I found the information from the Internet. . . School ranking to me 
is not important. But, for other Korean students, in other fields, they would think ranking is important. For me, program and professors are more important. . . Professor, program, and then funding.

Some international students sent e-mails to authors of journal articles and books whose research areas were of interest. They asked these authors/professors for assistance in directing their search towards a particular program of study and in providing recommendations as to which schools to apply.

How did I know which schools to apply? Through my professors, and the Internet, and I had already read the books and articles of professors that I wanted to work with. . I I contacted the authors of those papers and sent e-mails to them, some of them replied, but some didn't. Also, some North American scientists visited my university to do some seminars, and I talked to them and asked them how I can get to the States to study. They recommended that I can talk to this person, so I can look at the website, so I contacted those people and they are professors at the universities. . The Internet is very important and it is the only source. . How I chose the school was based on the professors, like my research interest is within professor's research interest. I just looked at the professors.

\section{Future Plans}

Most of these students expected they would be very mobile with their Canadian graduate degree. The survey results indicated that many of these international students would like to work in an international environment. In general, they have many options available to them. For example, more than half of the international students interviewed commented that they had either applied for landed immigrant status or they intended to apply; a quarter of the international students interviewed said they would like to stay in Canada permanently, and another quarter of them said they would definitely go back to their home country. Some of them said that they had not yet decided if they would stay in Canada, and that it would depend on career opportunities in the United States, Asia, or Europe.

In reviewing the main sets of factors influencing the choice of a Canadian graduate school, both survey and interview findings showed that the factors related to the Canadian graduate school had the strongest influence, followed by the factors related to Canada, and then the factors related to study abroad decisions. Institutional characteristics (both academic and administrative) had the strongest influence on international students when choosing a Canadian graduate school, followed by factors related to the Canadian environment, economic factors, and visa/immigration factors. Factors related to marketing, information, significant others, and Canada-home relationships had little influence on the decision-making process. Adding to previous studies, this 
study employed the push-pull model to understand students' choices of Canadian graduate schools. At the final choice stage, while the pulling factors from Canada and Canadian higher educational institutions exerted the most significant influence on international students' enrolment decisions, there was indeed another set of strong push-pull factors from the third countries. For example, due to the geographic proximity to the U.S., international students were pulled to North America, but again, were pushed away from the U.S. and pushed toward Canadian graduate schools.

To provide a summary of the factors studied in this research, Figure 1 depicts the strengths of the pulling factors in making an enrolment decision of a Canadian graduate school. There are four levels of circles in Figure 1: the core represents the enrolment decision; the innermost circle, Academic Pulling Factors, is the dominant influence, followed by Administrative Pulling and Economic Factors in the middle circle; the outermost circle represents factors such as Canadian Environment, Visa/ Immigration, and Proximity to the U.S., with moderate influence on the enrolment decision. Outside of the circles, at the periphery, four factors show a weak to moderate influence on the choice of Canadian graduate school. They are Marketing of Canadian Education, Information on Studying in Canada, Push Factors from Home Country to Canada, and Push Factors from Third Countries to Canada. The top half of the periphery represents the pulling factors, while the bottom half of the periphery represents the pushing factors.

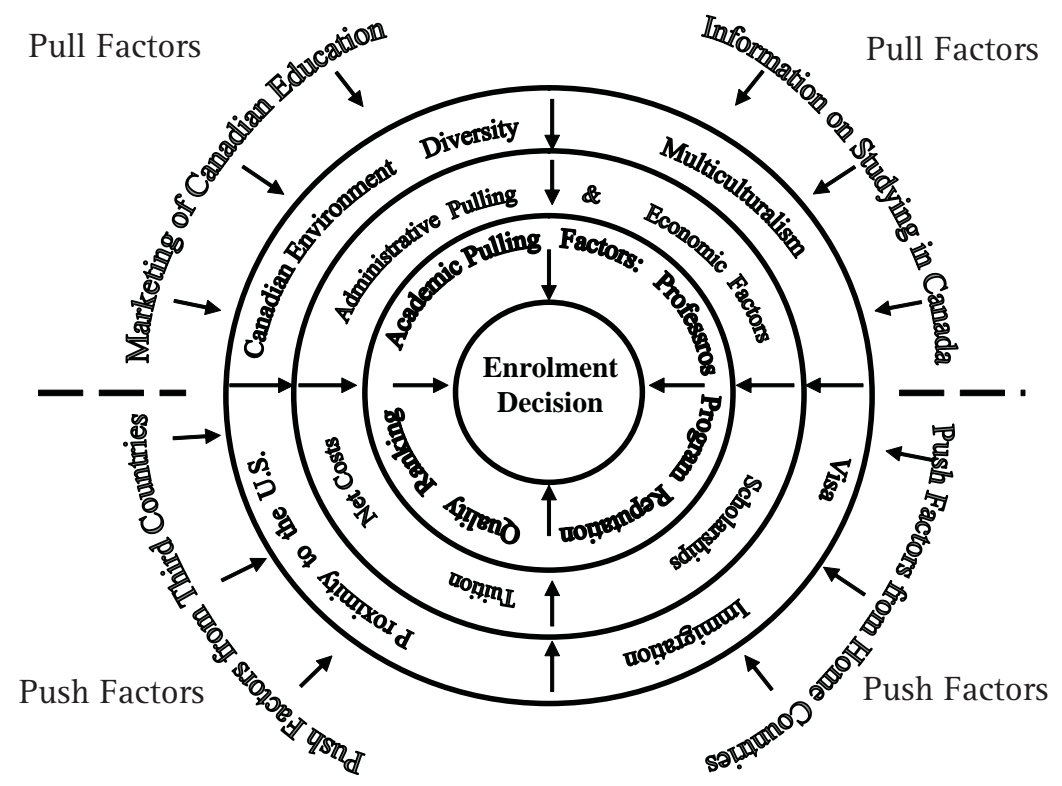

Figure 1.

The Strength of the Factors in Choosing a Canadian Graduate School 


\section{DISCUSSION AND ANALYSIS}

This section addresses two policy issues that emerged from the interviews: first, why international graduate students did not choose other English-speaking countries, and second, the future outlook for Canadian higher education with respect to international students.

\section{Why Didn't International Graduate Students Choose Other English-speaking Countries?}

Many international students considered other English-speaking countries while they were searching and gathering study abroad information. The most frequently mentioned countries were Australia, the United Kingdom, and the United States. However, at a later stage of the decision-making process, these students decided not to pursue studies in these countries. Some common reasons that turned international students away from those countries included the higher cost of education, length of the program, academic credibility, research environment, political relations, discrimination, and visa availability. In effect, these reasons represented another set of negative push factors from third countries - international students were pushed away from them and pushed toward selecting Canadian graduate schools.

These international students said they shied away from Australian graduate schools for two main reasons - the academic year cycle and image problems. Study participants found that the Australian academic year cycle did not coincide with the school year in their home countries, which was an important factor for those students who wanted to continue their graduate studies right after their undergraduate programs. Australia's aggressive marketing and recruiting effort targeting undergraduate studies in the East Asian countries has had a negative impact on highly qualified potential graduate students. They saw Australian universities mainly for under-prepared undergraduate students who could not pass university entrance examinations in their home countries. They associated this with poor quality or lack of academic credibility on the part of the university. This may in part explain why Australia is challenged in attracting highly-qualified graduate students from these East Asian countries.

The universities in the United Kingdom were generally considered to be of high quality by these international students. The most mentioned reasons for not choosing the British universities were the higher cost of living and tuition fees and the length of the programs.

As discussed earlier, the United States was the first choice country for many international students. The interviews revealed factors that pushed international students away from choosing American universities: visa, political relations, research environment, fear of discrimination/not fitting in, and the higher cost. 
Visa was the most mentioned reason for Chinese students not to go to the American universities. This was a strong negative push factor that pushed Chinese student away from the United States and pushed them toward to Canada. Two students mentioned political relations and political stability as factors for not choosing the United States as a host country, and they were concerned about security and safety. International students, in general, considered the research environment to be better in the United States, mostly because there is more funding for research and closer ties to the technology and to corporations. However, a few international students stated that they preferred the research environment and the working atmosphere and style in Canadian graduate schools to their American counterparts, despite American universities offering more scholarships to their graduate students. A few of the Japanese students said that their fear of discrimination or their fear of not fitting in were their reasons for not choosing American graduate schools. Many international students, especially self-funded and/or Masters students, considered the cost of education to be an important factor. Many students stated that the tuition fees in the United States were much higher, and they would get "the same degrees at a lower rate" in Canada.

These negative push factors from third countries made Canada and Canadian graduate schools the preferred host country and host institutions. It is apparent that these international graduate students regarded American education highly in terms of research capability or areas of expertise, but they also considered Canadian graduate schools as strong substitutes because of the good quality of education. In addition, unlike Australia, Canada does not have an image problem. In comparing the cost of education, Canada compares favourably with the British and American schools. In considering all these factors, the cost of education factor needs close monitoring, as cost is a controllable factor and these international students are sensitive to the cost issue. Other factors, such as the cultural environment and the perception of quality, are difficult to manipulate, and Canada already ranks favourably in this regard.

\section{Situation Analysis - The Future Outlook for Canadian Higher Education with Respect to International Students}

These findings have implications for the future outlook for Canadian higher education with respect to international students. Based on the research findings, Canada and Canadian higher education possess the following positive characteristics: a positive country image - a peaceful country, a diverse and tolerant society; a straightforward visa process and reasonable ease of obtaining a student visa; a good reputation for a quality education and research capability; a wide variety of program specialties, research projects, and strong faculty; and relatively low tuition fees and living expenses.

In the post-September 11 era, some international students prefer to pursue foreign graduate studies in a country perceived to be more peaceful and politically stable. They feel more than ever the importance of the diversity and tolerance 
of a society when choosing a host country, which supports Florida's theory of "the holders of creative capital - who prefer places that are diverse, tolerant and open to new ideas" (2002, p. 223). Although the visa process is viewed as lengthy by some students, the ease of obtaining a Canadian student visa makes Canada an attractive host country. At the institutional level, Canadian higher educational institutions enjoy good reputations and are perceived as having a high quality of research and strong academic capabilities. Program specialties, research projects, and faculty members have contributed much to the success and the high-perceived value of Canadian higher education. The program length, lower tuition fees, and living expenses and all the strengths presented here make Canada a very attractive host country and Canadian higher educational institutions strongly desirable.

Based on these strengths, it is reasonable to expect the future outlook for Canadian higher educational institutions regarding international students to be favourable. If international students continue to turn away voluntarily or involuntarily from the United States, Canadian higher educational institutions will be able to select international students from a very competitive candidate pool. There is nevertheless a significant risk to Canada if the United States chooses in future to relax its visa requirements, especially for students from China. This is a critical moment for Canada and its higher educational institutions to craft a strategy in regards to international students and set a direction that will enhance both the national and institutional interest.

The research findings support those of Mazzoral et al. (2001) in that potential international students had more difficulty in obtaining information about studying in Canada than other countries. The fact that Canadian education is not well known in these East Asian countries means that potential students have at least a neutral opinion of Canadian education and have not had an opportunity to form a negative perception of Canadian education. Moreover, as interview findings reveal, many international students chose to come to Canada because of the activities of internationalization and recommendations from their professors. Therefore, the weakness of availability of information on study in Canada is relatively easy to overcome because the dissemination of information can be accomplished through both marketing efforts and internationalization activities.

There are some opportunities available to Canada. Proximity to the United States and a similar education system make Canada and Canadian higher educational institutions attractive alternatives to the United States and American graduate schools. As international students are in general familiar with the American education system, there is an opportunity for Canada and Canadian higher educational institutions to promote the fact that the Canadian educational system is similar from the perspectives of students.

Potential threats to Canadian higher educational institutions regarding international graduate students are related to three recent developments: first, the expansion of domestic higher education in these East Asian countries, second, 
the creation of "branch campuses" in these countries and the development of on-line delivery of courses (Mazzarol, Soutar, \& Seng, 2003), and third, bilateral and multilateral strategic alliances among research universities in the Asian Pacific region and in the world, such as the International Alliance of Research Universities launched in January 2006. Many of the international students reported a huge expansion of their domestic higher education system - at both the undergraduate and graduate levels, with more public and private universities. The threat for all countries that provide education services to international students is a decrease in the number of enrolments, since there are more opportunities for students to pursue domestic graduate education. Increasingly, students challenged by the affordability of foreign education have the alternative to stay in their home country to complete their master's or doctoral degrees. Therefore, low cost tuition and the availability of scholarships and financial aid will continue to be important factors in attracting international students.

On the other hand, the motivations for studying abroad are multiple, and international students are looking for more than just a graduate degree from a Western university. Specifically from the market segmentation perspective, there will always be a group of international graduate students who want not only to improve their English language skills, but more importantly, to experience Western culture, gain international learning and working experience, and to form a network of friends and colleagues beyond their own borders. This is where the process approach to internationalization of graduate education, which is the prevalent approach taken by Canadian higher education institutions (Fortin, 2001; Knight, 2000), becomes extremely valuable to international students who have traveled from afar to fulfill intellectual and personal pursuits. Domestic graduate programs or "branch campuses" cannot provide these benefits for this particular group of international graduate students.

The expansion of local higher education systems may have an impact on the enrolment numbers; however, it also presents Canadian higher educational institutions with an opportunity to increase exchange activities and strategic alliances in research.

\section{Implications for Canadian Governments and Canadian Graduate Education Education/Immigration/Mobility}

This research explored the relationship between education, immigration, and the mobility of the overseas graduate students. International students perceived that with a Canadian graduate education, they would be highly mobile, and many stated that they could stay in Canada, go to the United States, go to Europe, or return to their home country after completing their studies. This attitude supports the concept of "brain circulation" in the context of the globalized economy (Cao, 1996; Saxenian, 2002; Yatsko, 2002). Thirtysix percent of the survey respondents ranked "the possibility of applying for immigrant status" with high importance ( 4 and 5 in the Likert scale) in choosing 
Canada as a host country. By reviewing international students' future plans, the research findings shed some light on the relationship between education, immigration, and mobility. Twenty-eight percent of the respondents agreed that they would like to stay in Canada permanently, and forty-seven percent of the respondents agreed that they would like to stay in Canada for a short period of time. Thirty-six percent of the respondents reported that they would like to go to another country, which indicates the existence of pull factors from other countries and a relatively weak loyalty for these students to Canada. The implication is that Canadian policy makers need to take action if we want to retain these students.

Two implications emerged from these data. First, students who apply to study in Canada may also have a positive attitude towards immigrating: more than one-third of these students came to Canada with the possibility of immigrating to Canada in mind. This acts in Canada's favour in attracting and retaining highly talented workers from around the world, and Canada should be able to continue to attract this group of people as potential immigrants. Second, due to the fact that these are international graduate students, who can be categorized as highly skilled workers in the world market, they are highly mobile and their future plans are not fixed. The economics of overseas graduate education is important for them, and they will likely choose a path that generates a high return on their investment. In other words, they will go to a place where they can have a satisfying career experience and a high monetary return. The implication is that if Canada can create an economically competitive environment, in addition to its favourable social environment, it will be best able to retain these "best and brightest" international students.

This analysis focuses on the host country perspective. The immigration decision has implications for home countries as well. Kapur and McHale (2005) have documented the mixed consequences for developing countries when knowledge workers emigrate. The consequences of brain drain are heterogeneously distributed by region. Docquier and Marfouk (2006, p. 167-177) present data showing that the emigration rate of workers with postsecondary education defined as the proportion of those born in a region who live outside the region - is lower for East Asia than for any region other than North America.

\section{Graduate Education - Core Competencies}

International graduate students came to Canada for academic reasons, such as university/program reputation, quality and ranking. These, in turn, are largely driven by the core competencies of graduate education - especially the strength of the research and knowledge creation. These international students often mentioned the faculty and their research topics as important factors influencing their choice of a Canadian graduate school.

At the graduate level, reputation and quality can hardly be manipulated by regular marketing hype. At the "search/selection/application" stage, some international students looked for books and other academic publications written 
by university faculty members and contacted the authors directly to gather information about where they should apply. During the application process, it was the one-on-one interaction and contact with the faculty and staff that pulled international students closer to the enrolment decision. In essence, research, creation of knowledge and publication are at the core of a high quality of graduate education, and without these elements, a graduate program and a university will not be able to attain a great reputation and be considered high quality.

As Figure 1 illustrates, the innermost circle - Academic Pulling Factors - is the magnet for attracting international graduate students to Canada. This is an argument for strengthening Canadian graduate education by investing in research and by attracting and encouraging "the best and brightest" to pursue graduate education, conduct research and create knowledge.

Strengthening Canadian graduate education will enhance its overall quality, and the spill-over effect will influence international students at all levels to choose Canada as a study destination. Investing in research and ensuring the quality of graduate education are indeed the most important ingredients in building "country loyalty" and "brand awareness," as excellence in higher education and a high quality of research draw international graduate students to Canada. Canada will eventually gain an image as a place of excellence in higher learning. Therefore, strengthening the core competencies by investing in graduate education and research is crucial to the future of Canadian education, and the benefits of strengthening Canadian graduate education extend well beyond attracting international students.

In addition, investing in research and innovation is directly correlated to a country's productivity and prosperity (Romer, 2007; Task Force on Competitiveness Productivity and Economic Progress Ontario, 2003), which also helps attract the "best and brightest" from elsewhere who contribute further to the creation of knowledge, the betterment of society, and even to improved international relations. International graduate students, who belong to the "creative class" (Florida, 2002) and are highly mobile, will choose a destination that promises prosperity and an environment that supports creativity and innovation for their studies. Many may choose to remain in Canada after graduation. A prosperous economy depends on a highly educated work force and a strong research capability (Government of Canada, 2004; Task Force on Competitiveness Productivity and Economic Progress Ontario, 2003, 2004). It is in the national interest to attract the "best and brightest" international students as a complement for their domestic counterparts. This extends to direct investment in international graduate students, via financial aid which supports the enrolment decision. However, it is important to note that financial aid by itself will not be enough to induce enrolment decisions because the core competencies - reputation, quality, ranking, and research capabilities - play far more important roles in attracting students. Therefore, effectiveness in recruiting international graduate students in research-oriented 
programs requires both strengthening the core competencies and also providing competitive financial support.

\section{Internationalization of Canadian Graduate Education}

Harari defined internationalization as "the international content of the curricula, the international movement of scholars and students concerned with training and research, and the arrangements that engage a system of education cooperation programs beyond its national boundaries" (1977, p. 2293). This "activity" approach (de Wit, 2002) is most applicable to international students. In interviews in which they described how they chose to study in a Canadian graduate school, one of the very important pulling factors was meeting their current professor during "international" activities. The three most mentioned activities were international conferences, presentations by guest speakers, and exchange programs. Many of the international graduate students met their current professors at international conferences; some met their current professors in their home country where the latter were invited to be guest speakers; and some met their current professors because professors in their home country had exchanges or working experience with their current professors. A small percentage of students mentioned that they themselves had participated in exchange programs.

Internationalization activities benefit both higher educational institutions and international graduate students. Overall, there are at least four major benefits of internationalization activities accruing to international graduate students throughout the whole process of overseas graduate study and beyond. First, these activities help Canadian higher educational institutions promote the institutions' profiles and reputation, which helps increase awareness of Canadian graduate education among the international academic society. In turn, these activities create a virtuous circle, helping prospective international students in gathering study-abroad information and in learning about new research projects/directions during the "predisposition" and "search/selection/ application" stages, and subsequently, in making their enrolment decisions. Secondly, international activities in Canadian institutions provide all students and international students in particular with opportunities to gain knowledge in various subject areas from professors and students of different backgrounds. Thirdly, these international students are typically economically sensitive, and in general, they pay attention to the return on their investment. Most international graduate students said that they would like to work in an international environment in the future. This means that the more international activities the university and program arrange, the higher the profile they would enjoy and the more international employers would be familiar with graduates from these universities and programs. Consequently, international students benefit from possible future career enhancements and improved job prospects in an international setting. Finally, those who intend to emigrate to North America gain opportunities to explore the best environment for their studies and future 
careers through these international activities. This also benefits Canada, as Canada would like to attract and retain the best and brightest international students as immigrants.

It is clear that internationalizing Canadian higher education is crucial to attracting international students. The nature of graduate education and research involves scholarly exchanges, and the milieu is typically in international settings, and these require greater support for and commitment to the internationalization of higher education at the institutional level. Examples of this kind of support and commitment include publishing research papers, presenting research results at international conferences, and promoting exchange programs for international faculty and students. However, these internationalization activities are a bare minimum; strategically, Canadian universities should take on a more proactive role in developing bilateral or multilateral strategic intra- and interregional alliances. As seen by recent developments, such as the formation of the International Alliance of Research Universities, more countries and research universities are engaging in these strategic alliances. It is critical that Canadian research universities engage in these activities and become members of research university consortia. Therefore, the findings from this study argue for devoting more government and institutional resources to the objective of internationalizing Canadian higher education.

In essence, internationalizing Canadian graduate education through these activities is a soft way, and perhaps the best way, to market Canadian graduate education to international graduate students. Indeed, by participating in international activities such as conferences, faculty-student exchange programs and strategic alliances, universities are engaging in marketing their research capabilities and program quality, and in increasing their institutional profiles; as a consequence, the core competencies of Canadian graduate education are promoted through the internationalization effort.

\section{CONCLUSION}

This research, the first study focusing on college choice by international graduate students, offers some useful insights on why East Asian students choose Canadian graduate schools. It reveals that international students are attracted by the strong pulling factors related to the perceived high quality of Canadian graduate programs and the diverse, multicultural, and tolerant Canadian environment. It finds that many students, especially those from China, choose Canada because of the difficulties in obtaining a visa in the United States - a strong negative pushing factor from the United States and also a strong pulling factor for Canada, which benefits from its geographic proximity to the United States. In addition, the activity approach to the internationalization of higher education plays a critical role in guiding these international graduate students' decision-making processes and represents a strong factor in pulling these students to Canadian graduate schools. 
This research suggests that to advance the national goal of being "a magnet for talent" and "a destination of choice for talented foreign students," policy makers and university administrators should focus on two things: first, to strengthen Canada's core competencies by investing in research and ensuring the quality of graduate education, and second, to devote efforts and resources to the internationalization of higher education, especially graduate education and research.

More research is needed to understand other aspects of the "college choice" process of international students. It is hoped that this study will generate further discussion and research in this area.

\section{ACKNOWLEDGEMENTS}

I would like to express my sincere appreciation to the three anonymous reviewers for their comments and feedback, which have helped to strengthen this paper. This paper honours the memory of Dr. Berta Vigil Laden, Associate Professor of Higher Education, OISE/UT, whose advice and encouragement inspired me to publish my research results.

\section{REFERENCES}

Agarwal, V. B., \& Winkler, D. R. (1985). Foreign demand for United States higher education: A study of developing countries in the eastern hemisphere. Economic Development and Cultural Change, 33(3), 623-644.

Altbach, P. G., \& Lulat, Y. G.-M. (1985). International students in comparative perspective: Toward a political economy of international study. In J. D. Smart (Ed.), Higher education: Handbook of theory and research (Vol. 1, pp. 439-494). New York, NY: Agathon Press.

Austin, M. (1988). Asian electrical and computer engineers at a California university: Why are they here? Why might they stay? U.S.; California: University of California, Santa Barbara.

Bartlett, K., \& Kane, M. (2002). The national report on international students in Canada 2000/01. Ottawa, ON: The Canadian Bureau for International Education.

Canadian Association for Graduate Studies. (2004). 1990-2001 Statistical report. Ottawa: Canadian Association for Graduate Studies.

Cao, X. (1996). Debating "brain drain" in the context of globalisation. Compare, 26(3), 269-285.

Chen, T.-M., \& Barnett, G. A. (2000). Research on international student flows from a macro perspective: A network analysis of 1985, 1989 and 1995. Higher Education, 39(4), 435-453. 
Citizenship and Immigration Canada. (2003, January). Foreign students in Canada 1980-2001, from http://www.cic.gc.ca/english/research/papers/ foreignstudents/students-toc.html

Cummings, W. K. (1984). Going overseas for higher education: The Asian experience. Comparative Education Review, 28(2), 241-257.

Cummings, W. K., \& So, W.-C. (1985). The preference of Asian overseas students for the United States: An examination of the context. Higher Education, 14(4), 403-423.

Davies, J. L. (1997). A European agenda for change for higher education in the XXIst century: Comparative analysis of twenty institutional case studies. CRE-action, 111, 47-92.

Davis, T. M. (2000). Open doors: Report on international educational exchange. New York, NY: Institute of International Education.

de Wit, H. (2002). Internationalization of higher education in the United States of America and Europe: a historical, comparative, and conceptual analysis. Westport, CT: Greenwood Press.

Docquier, F., \& Marfouk, A. (2006). International migration by education attainment, 1990-2000. In Ç. Özden \& M. W. Schiff (Eds.), International migration, remittances, and brain drain (pp. 151-200). Washington, DC: World Bank.

Florida, R. (2002). The rise of the creative class and how it's transforming work, leisure, community and everyday life. New York, NY: Basic Books.

Fortin, J.-L. (2001, April). From intention to reality, from www.aucc.ca/_ pdf/english/reports/2001/intconf_fortin_e.pdf

Gagnon, J. P., \& Cocolas, G. H. (1988). Understanding what motivates someone to pursue pharmacy graduate education. American Journal of Pharmaceutical Education, 52(1), 10-15.

Gertler, M. S., Florida, R., Gates, G., \& Vinodrai, T. (2002). Competing on creativity: Placing Ontario's cities in North American context, from http://www. competeprosper.ca/research/Competing0nCreativity_061202.pdf

Glaser, W. A., \& Habers, E. (1978). The brain drain: Emigration and return. Findings of a UNITAR multinational comparative survey of professional personnel of developing countries who study abroad. Oxford; New York: Pergamon Press.

Government of Canada. (2002, September 30). The Canada we want - speech from the throne to open the second session of the thirty-seventh parliament of Canada. Retrieved June 2, 2003, from http://www.pco-bcp.gc.ca/sft-ddt/sft. htm

Government of Canada. (2004, October 5). Speech From the throne to ppen the second session of the thirty-eighth parliament of Canada. Retrieved December 9, 2004, from http://pm.gc.ca/eng/sft-ddt.asp 
Harari, M. (1977). Internationalization of higher education. In A. S. Knowles (Ed.), The international encyclopedia of higher education. San Francisco, CA: Jossey-Bass.

Hossler, D. R., \& Gallagher, K. S. (1987). Studying student college choice: A three-phase model and the implications for policymakers. College and University, 62(3), 207-212.

Kapur, D., \& McHale, J. (2005). Give us your best and brightest: The global hunt for talent and its impact on the developing world. Washington, D.C.: Center for Global Development.

Knight, J. (2000). Progress \& promise: The AUCC reporton internationalization at Canadian universities. Ottawa: AUCC.

Lee, E. S. (1966). A theory of migration. Demography, 3(1), 47-57.

Lee, K. H., \& Tan, J. P. (1984). The international flow of third level lesser developed country students to developed countries: Determinants and implications. Higher Education, 13(6), 687-707.

Mazzarol, T., \& Soutar, G. (2002). "Push-pull" factors influencing international student destination choice. The International Journal of Educational Management, 16(2), 82-90.

Mazzarol, T., Soutar, G., \& Seng, M. S. Y. (2003). The third wave: Future trends in international education. International Journal of Educational Management, 17(3), 90-99.

Mazzarol, T., Soutar, G., Smart, D., \& Choo, S. (2001). Perceptions, information and choice: Understanding how Chinese students select a country for overseas study. Canberra, ACT: Australian Education International Department of Education, Training and Youth Affairs.

McMahon, M. E. (1992). Higher education in a world market: An historical look at the global context of international Study. Higher Education, 24(4), 465482.

Neice, D. C., \& Braun, P. H. (1977). Patron for the world. Ottawa, Ontario: Canadian Bureau for International Education.

Olson, C. (1992). Is your institution user-friendly? Essential elements of successful graduate student recruitment. College and University, 67(3), 203-214.

Poock, M. C., \& Love, P. G. (2001). Factors influencing the program choice of doctoral students in higher education administration. NASPA Journal, 38(2), 203-223.

Rao, G. L. (1979). Brain-drain and foreign students: a study of the attitudes and intentions of foreign students in Australia, the U.S.A., Canada, and France. St. Lucia: University of Queensland Press. 
Romer, P. M. (2007). Economic growth. In D. R. Henderson (Ed.), The concise encyclopedia of economics. Indianapolis: Liberty Fund.

Saxenian, A. (2002). Brain circulation: How high-skill immigration makes everyone better off. The brookings review, 20(1), 28-31.

Sirowy, L., \& Inkeles, A. (1984). University-level student exchanges: The U.S. role in global perspective. In E. G. Barber (Ed.), Foreign student flows: Their significance for American higher education (pp. 31-85). Spring Hill Center, Wayzata, Minnesota: Institute of International Education.

Task Force on Competitiveness Productivity and Economic Progress Ontario. (2003). Investing for prosperity - second annual report. Toronto: Institute for Competitiveness \& Prosperity (Ontario).

Task Force on Competitiveness Productivity and Economic Progress Ontario. (2004). Realizing our property potential - third annual report. Toronto: Institute for Competitiveness \& Prosperity (Ontario).

Webb, M. S. (1993). Variables influencing graduate business students' college selections. College and University, 68(1), 38-46.

Yatsko, P. (2002). Brain circulation, from http://www.forbes.com/ global/2002/0916/058.html

Zikopoulos, M., \& Barber, E. G. (1986). Choosing schools from afar. The selection of colleges and universities in the United States by foreign students. New York, NY: Institute of International Education, New York, NY.

\section{CONTACT INFORMATION}

Liang-Hsuan Chen

Department of Management, University of Toronto at Scarborough

1265 Military Trail, Toronto, Ontario M1C 1A4

e-mail: liangc@utsc.utoronto.ca

Liang-Hsuan Chen is a lecturer in Accounting in the Department of Management at the University of Toronto at Scarborough and an associate member of the faculty at the Ontario Institute for Studies in Education of the University of Toronto (OISE/UT). Her research interests include college choice, graduate education, international education, professional education, teaching and learning, and the student experience. She is currently developing an on-line learning project in financial accounting and is researching the learning experience and aspirations of international students. Liang is an elected member of the Board of Governors of the Certified General Accountants of Ontario. She holds an MSEd from the University of Pennsylvania, an MBA from the University of Toronto, and a PhD in Higher Education from OISE/UT. 